\title{
THE CROOKEDNESS CLINIC OF NICHOLAS AND PETER SCHOT
}

\author{
William Brockbank, MANChester, ENGland
}

There can be no better way of learning about doctors, patients and the sick-room than by reading contemporary diaries, particularly those written by parsons. An interesting example is the case note on sixteen-year-old Edmund Verney, son of Sir Ralph Verney of Claydon House. The story can be found in the third volume of The Memoirs of the Verney Family during the Commonwealth, compiled from family letters and documents by Margaret Maria Lady Verney, published in 1894.

Mun, as he was called, was born on Christmas Day, 1636. Two years later he was described as "a strapping boy giving promise of health and long life." He was brought up by his grandmother. At the age of three he was " rustic and bashful" and his parents, who were strangers to him, were disappointed that he did not take to them. The old lady pleaded for her "sweet child" and begged his father not to whip him. "Be shore that he is not frited by no menes: he is of a gentle sweet nature sone corrected." He was a fine tall boy at the age of seven and at eleven he was described as thriving in stature and learning. His mother died when he was fourteen, and shortly afterwards he was taken by his father on a grand tour abroad.

He was completing another tour at the age of sixteen with his father and tutor, Dr Creighton, D.D., when the relevant passages commence. Dr Creighton, a Royalist in exile, afterwards became the Bishop of Bath and Wells. Lady Verney takes up the story:

"December 24, 1652. As we have seen he (Sir Ralph) left Mun at the Hague with Dr Creighton, and they went on to Utrecht. The boy was overgrown and weak; his ' governor' wishes to consult Myen Herr Skatt (or Schott), who has a great reputation at Utrecht for his treatment of crooked children. 'If they be young,' writes Dr Creighton, ' the sooner are they cured, and he selldome undertakes old people, becaus invetrat ills especiallie when they come by nature are hardlie removed; yett hath he done such cures to wonder, upon some of 50 yeares and upward, but selldomer: from the craddle to the ages of 30 or 40 ar his patients, all sexes, ranks, qualities, and conditiones, and young people have beene brought to him from further then the uttmost parts of Shettland or the Orcades, even from Swedland, Denmark, Holsteyne, \&c. And this is his way, If when he look upon the partie he fynd the defect curable he undertaks it, and $w^{\text {th }}$ out bargayne expects such an honest reward as the partie is or willing or able to bestow; and trulie I could never lerne or heare but that he was an exceeding honest conscientious man. If he sees nature so defective or so much collapsed that it is incurable, he will not undertake it." "...

January 28, 1652. Dr Creighton is writing:

" Truly I wold never have thought he could have beene so crooked if I had not seene (it). The backbone in which all the fault lies is quyt awry and his right shoulder half a handfull lower at least than his left. Herr Skatt hath undertaken the cure, if your sonne will stay heere three quarters of a yeare; and alreadie he is about to make harnessing for him which your soone is very willinge for ought I can perceive to undergo."

Sir Ralph Verney to Dr Creighton, February 18, 1652(3).

"I thanke you for your care of Muns crookednesse if you (upon conferring with others that have had experience of $\mathrm{y}^{\mathrm{e}}$ Mans practises) conceive hee can cure Mun, soe as to make him absolutely streight, I am content he should begin the cure as soone as 
you and hee thinke fit but I think it necessary that you should first know what hee expects for his reward least hee proove unreasonable afterwards; for tis usual with some of that profession, to make very imoderate demands, not only for theire paines and skill but also for such bathes, Oyntments, Irons, and such like matters as shall bee requisite for the worke. In my opinion tis best agreeing with him for altogether in grosse. I pray informe me what you doe in this as soone as conveniently you can."

Dr R. Creighton to Sir Ralph Verney, February 18, 1652.

"Mr Verney is very well god be praised, and this day hath enterd his harness; that rare man hath wrought a miracle upon my L.(ord) Gerard, and to him fr. all parts of Europe people flock in great abundance. He doubts nothing of Mr V."

Dr R. Creighton to Sir Ralph Verney, February 4, 1652.

"I could not agree with $\mathrm{Mr}$ Skatt as you commanded in $\mathrm{yo}^{\mathrm{r}} \mathrm{le}^{\mathrm{rs}}$, nor doth he bargayne (?) $w^{\text {th }}$ any man, it is not his custome, nor manner of proceeding: and in that poynt he is very superstitious: If he cannot cure, though he upon entreatie may trie and miss, yett he taks nothing, accounts his labor lost, and if he do cure, as he is so judicious that he hardlie undertaks anything what he brings not to pass, then he taks so reasoneable (as I am enformed by all that know him, and in speciall by an English chirurgian who lives heere, and is a kynd of retayner to his house) that they who receive benefitt by him ar willing oftymes to give more then he is willing to take. He hath beene in harness two weeks, so fynely fitted for his crookedness as yett I never saw any thing: It is perfyt massive irone all along (excepting $\mathrm{su}^{\mathrm{m}}$ holes heere and ther, wheer he pleaseth) back and breast, lyned $w^{\text {th }}$ quilted fustiane and all so light as is wonderfull: This I say he hath worne two weekes, and $\mathrm{su}^{\mathrm{m}}$ dayes: At first when he putt them on, he fellt no payne, or pressure at all, but at (?) upon his haunchebone of his left syde, wher the $\operatorname{arm}^{\mathrm{r}}$ to keepe him up towards the right syde, gav him a little twitch now and then upon that bone. Mr V. wold fayne have had it cutt a little shorter, but Mr Skatt wold in no wayes be brought unto it: in less then a weeke that payn went away, and then he fellt his harness $\mathrm{su}^{\mathrm{m}}$ what loose upon him, wherupon we the second tyme went to him to lett him see, who streithned it, by pinning sum iron buttones closer, and drawing sum strings, but then $\mathrm{Mr} \mathrm{V}$. fellt greate payne in his right shoulder then befor he hade fellt on his haunchebone, insomuch that all night he slept very ill, it lay so hard upon that shoulder, and yett I could not obtayne the relaxation of one hayre bredthe and now the payne is allmost quyte gone, he playes on the Lute, follwes his other studies, goes abroade, to dinner, to the fields, enjoyes his health, God be praised, and is what he was befor, only that right arme he can scarcely raise to combe his heade, by reason of the straitness of that harness towards the right shoulder: And Mr Skatt doth not doubt but to make him as straight, as any in Christendom $w^{\text {th }}$ in these six Moneths and less, once he sayd nyne Moneths now he says six: and when you pay him you ar in the same condition $w^{\text {th }}$ My L. Ger: and thowsands more that flock to him from all parts of Germany and Denmark: For he never makes bargaynes and to do as others, as all men do, I hope you will not think it amiss: $\mathrm{Mr} \mathrm{V}$. weares his harness under his doublett very patiently, more than I ever expected: and truly Sir, he is no ill conditioned youth: I have beene in his company now six Moneths full, and I know not any vice in the world to ${ }^{\text {ch }}$ he is inclined: extreamly civill, and free fro all intemperance; eates his meate hartily, drinks very little wyne, grows tall apace, but will shoote out extremely, when his crookedness is gone, wch did not a little pinch and hold back his growth: One thing I must putt you in mynd off, you did ill forgett, that shute of cloath wch I so often wrott to you for, and $w^{\text {ch }}$ you promised to send: and you must take heede what you promise to young men, who will daily call for a performance, his last cloth sute ${ }^{\text {ch }}$ I made heere I gott the 
tailor to lett it out in the seames for his harness, and becaus he could weare no waistcoate $\mathrm{w}^{\text {th }}$ that harness, and his armes were all bare but his shirt and doublett, I made him a payr of sleeves of scarlet bayes, to keep him warme, $w^{\text {ch }}$ he weares night and day: For Mr Skatt desired he should be kept fro cold, eate no badd meate, no oysters, nor such things as might endanger his health, or hinder his purposes towards him. I have bought him su ${ }^{\mathrm{m}}$ few books too: he hath redd Salust all over and over, and is now in Livy, wch I have bought him $w^{\text {th }}$ Ceaesar's Commentaries and Quintilian at an auctione of books, this last weeke, and he goeth on very well in his booke and lute, other exercises as yett we have undertoke none, by reason of his straightgirding as I have told you: $w^{\text {th }}$ in a moneth or so I beleeve we shall fence at the fenceing schoole, wch $\mathrm{Mr}$ Skatt will allow him so soone as he is able to stirr his armes as he should, and that art requires, but he will not suffer him in any case to dance till he be perfytly cured and past his help or art."

Lady Verney once more takes up the story.

"July 8,1653 . Mun's harness is very irksome, especially in hot weather, and he complains that it galls him: but his governor reports in six months' time: ' I may truly say the cure is allmost perfyted, yet whilst he is under Herr Skatt, I think it wer no wayes for his good to remove him. My intention was to convey him to Leyden for his learneing, but I now conceive it was God's great mercie to send us hither from the Hague for rectifeeing of his body; the soule will (I hope) follow the better.'

"July 15, 1653. Dr Creighton writes again: ' He is very well, grows apace, and of his crookedness so allmost wholly restored, that very little difference is to be seene; and when his clothes and cloak is on without his harness none at all, yet he weares his harness for the most part continuallie, and must I am afrayed till the next spring by which tyme Her Skatt doth not doubt but to make him a perfyt man: and in the meane tyme becaus the weather is very hott in these moneths, he permitts him sum tymes for a two or 3 dayes together ease him self of his harness, and go in his single doublett, which I say he condiscends unto meerly to ease him from wearing iron bodies continuallie, though they be very light, and I think might well be borne at all tymes, and wer farr better borne, then left off at any time till the cure be finished.'

" The discomforts which the tutor felt were so easy (for somebody else) to bear come out vividly in Mun's letters, though the boy does not complain. The iron body fits tightly back and front, lined with soft leather; it is fastened by Herr Skatt over his linen shirt; Mun can neither undo it nor ease any undue pressure. His shirt in hot weather is always wet, but he cannot change it. Once a week he goes with his clean shirt over his arm, to have the armour taken off: his shirt and the leather lining are then 'as black as a chimney.' It does not appear that the skin was washed even at the weekly dressing, only that the leather lining was renewed. Sir Ralph asks whether the shirt could not be changed twice a week, but Mun replies that the great man has more than 2000 patientsmen and women, boys and girls-that he could never get through his work if they all came twice a week, and that many keep on the harness for a month together.

"The tutor continues his report: 'He growes apace upon my worde; in height ther is but little difference betweene him and I. He loves his ease very well, and his owne will above all things and though in truth I cannot accuse him of any vice or scandall, he is civill and temperat, yet he loves his bedd too well, and is very willfull, for the which two defaults I entreat you hartilie to chide him, for upon my worde he deserves it.'

"January 1654. Myen Herr Schott's bill is a heavy one (Dr Creighton writes) ' he is at great charges in maintayning 16 or 17 servants daily, and three sonnes very expert in his art, that do nothing but work in iron and steele, and brace and unbrace crooked limbs. They who have received benefitt by him use to present him with a goode peece of plate, or perhapps a round summe of monie, over and above his accounts; which they do 
cheerfullie, and he receives thankfullie, for he is noe unrasonable man. He hath done a notable cure on Mr Verney.'

"March 20, 1654. Mun manages to dance girt in his armour."

In May 1656 Edmund Verney returned home, a young man in his twentieth year. He had an affectionate and pleasant temper, he was tall and handsome, but somewhat clumsily and heavily built, and his awkwardness of manner and slovenliness of dress were a great trouble to his precise and gentlemanlike father.

"February 15, 1657. Herr Schott had come to London from Utrecht, and the 'bodies' at 30l the pair, which Mun still wore, were the heaviest of his expenses.

"March 5, 1657. Dancing lessons from Moulin, a fashionable French master, are strongly recommended; Mun agrees but his steel bodies make dancing almost too painful."

Poor Mun's luck never returned. He was shabby and untidy in his dress. When he was twenty his father wrote: "Mun is not at all nice either in point of bewty or breeding nor must that woman be so that marries him." He put on weight, reaching more than twenty stones. In spite of that he did find a wife and had three children. But they all died young and he himself failed to outlive his father, dying in 1688 at the age of fifty-one.

The curious reader has been left to wonder what sort of a person was " Myen Herr Skatt (or Schott)." E. M. Little was shown the correspondence by Lady Verney in 1903 and wrote an article on the subject. But though he made inquiries in Utrecht no trace of him could be found. He was satisfied that Schott was not a professional man, for in spite of his skill both Sir Ralph and Dr Creighton referred to him as "the man," a phrase which neither of them applied to physicians or surgeons when these were mentioned in other letters. He thought he must have been an artificer, probably an armourer who made steel " bodies " or " harness" something like the breast-plates and back pieces which were at that time worn by soldiers.

Some months ago I took up the trail myself but for a time met with no more success. Then one day my question reached the archivist of the town, $\mathrm{Mr} \mathrm{J}$. W. C. van Campen. I am most grateful to him for the following information. Claes (or Nicholas) and Peter Schot, sons of Jacob Claes Schot, had a great reputation as makers of orthopaedic appliances. Mr van Campen believes they were medical men. The Town Council decided on July 30, 1655. that the supplication of Nicholas and Peter Schot be granted out of consideration of their art. The brothers had asked for permission to mend the iron, copper or other instruments made by them to cure crooked hunchbacked and otherwise malformed limbs in their own house without interference from the Smiths' Guild. They stated that many people came to Utrecht from elsewhere to be healed by their art.

The Guild protested against this inroad on their monopoly and the Town Council decided that the brothers Schot should continue to make their instruments although they were not members of the Guild provided they gave instead 16 guilders to the poor of the Guild and the dues of the Guild to the Chairman and Examiners. In addition they had to promise not to accept any journeymen or apprentices who had not fulfilled their financial obligations towards their masters.

Peter died in August 1662, but Nicholas was allowed to continue his work on the same terms. A further record occurs in the Council's proceedings on June 25, 1666: " The Town Council takes into consideration that Nicholas Schot, a skilful doctor of crooked and dislocated limbs, has settled in this town, wherefore many people of importance come and stay here to be cured. To acknowledge this it has been decided to grant him freedom from taxes for all the wine and beer consumed in his household." At the same time the Town Council ordered the burgomasters to request the same freedom of taxes from the Provincial Council. This demand was considered on July 4, 1666, and referred to the Gedeputeerde Staten (a committee dealing with the daily administration of the province). But no resolution 
can be traced. It is clear from this that the Town valued greatly the work of Myen Herr Schot and met him half-way when there was possibly a danger that he would transfer his clinic elsewhere.

E. M. Little comments on a curious sidelight to this story. It seems odd that not one of the many patients who attended the clinic has left a record of the occurrence. There were two thousand patients attending at one time and they included English noblemen. What a pity it was that the "English Chirurgion" who was "a kynd of retayner of his house" has left no record of the brothers' clinics. But possibly one day further details will become available of this busy and successful orthopaedic clinic that existed nearly a century before the word orthopaedia was coined.

\section{REFERENCES}

Little, E. M. (1903): The Treatment of Spinal Curvature 250 Years Ago. British Medical Journal, ii, 89.

Verney, Lady F. P. (1892): Memoirs of the Verney Family during the Civil War, Vol. 2. London: Longmans, Green, and Co.

Verney Family (1853): Letters and Papers of the Verney Family Down to the End of the Year 1639. [Printed from the Original MSS. in the Possession of Sir Harry Verney, Bart. [Camden Society, 56.] London: Printed for the Camden Society.

Verney, M. M. Lady (1894-99): Memoirs of the Verney Family during the Commonwealth, Vols. 3 and 4. London: Longmans, Green, and Co. 